\title{
VISOKOŠKOLSKE USTANOVE U PODRUČJU BIOMEDICINE I ZDRAVSTVA BOSNE I HERCEGOVINE: PREGLED PRAVNIH NORMI
}

\author{
${ }^{1}$ Vedran Ramljak, ${ }^{2}$ Jelena Šimić, ${ }^{1,3}$ Magdalena Ramljak
}

${ }^{1}$ Fakultet zdravstvenih studija Sveučilišsta u Mostaru

${ }^{2}$ Ministarstvo zdravstva, rada i socijalne skrbi Županija Zapadnohercegovačka

${ }^{3}$ Filozofski fakultet Sveučilišta u Mostaru

Rad je primljen 29.08.2020.. Rad je recenziran 14.09.2020. Rad je prihvaćen 19.10.2020.

\section{SAŽETAK}

Područje obrazovanja, a samim time i područje visokog obrazovanja u Bosni i Hercegovini je u potpunoj nadležnosti deset županija u Federaciji Bosne i Hercegovine, entiteta Republika Srpska i Brčko distrikta Bosne i Hercegovine. Okvirni zakon o visokom obrazovanja u Bosni i Hercegovini usvojen je u lipnju 2007. godine, a stupio je na snagu 15. kolovoza 2007. godine. Okvirnim zakonom o visokom obrazovanju u Bosni i Hercegovino kao ciljevi visokog obrazovanja postavljeni su: ustanovljavanje, razvoj, štićenje i prijenos znanje i sposobnosti kroz nastavu i znanstvenoistraživački rad, doprinos razvoju sposobnosti pojedinaca i društva, pružanje mogućnost građanima da, sukladno propisima, cijeloga života uživaju korist visokog obrazovanja. Okvirnim zakonom o visokom obrazovanju u Bosni i Hercegovini utvrđena je podjela visokoškolskih ustanova na sveučilišta i visoke škole.

Visokoškolske ustanove u području biomedicine i zdravstva djeluju u relativno slabo sređenom pravnom okviru. Nepostojanje jasno reguliranih pravnih normi dovodi do slabog funkcioniranja u području obrazovanja i istraživanja biomedicine i zdravstva.

Ključne riječi: visoko obrazovanje, biomedicina i zdravstvo, pravne norme.

Osoba za razmjenu informacija:

Vedran Ramljak, mag. iur.

E-mail: vedran.ramljak@fzs.sum.ba 


\section{UVOD}

Ustavnim uređenjem Bosne i Hercegovine $(\mathrm{BiH})$ područje obrazovanja, a samim time i područje visokog obrazovanja, je u potpunoj nadležnosti deset županija u Federaciji Bosne i Hercegovine, entiteta Republika Srpska i Brčko distrikta BiH. Sve navedene razine vlasti imaju ustrojeno ministarstvo obrazovanja, nadležnost za donošenje zakona i pod zakonskih akata iz područja obrazovanja, kao i sva druga prava i obveze koje spadaju u djelokrug rada nadležne vlasti, te nadležnost za organizaciju i funkcioniranje obrazovanja na svom području odgovornosti. Na razini entiteta Federacija $\mathrm{BiH}$ organizirano je još i Federalno ministarstvo obrazovanja i znanosti koje nema stvarnu nadležnost u području obrazovanja već obavlja koordinacijsku ulogu. Od 2003. godine na razini $\mathrm{BiH}$ organizirano je i Ministarstvo civilnih poslova koje je na razini BiH nadležno za obavljanje različitih poslova koji se odnose na utvrdivanje temeljnih principa koordiniranja aktivnosti, usklađenosti planova entitetskih tijela vlasti i definiranje strategija na međunarodnoj razini u područjima: zdravstva i socijalne zaštite, mirovinskog sustava, rada i zapošljavanja, kulture i sporta, geodetskih, geoloških, meteoroloških poslova, te znanosti i visokog obrazovanja (1-4). Osnivanje visokoškolskih ustanova u području medicine i zdravstva nije samo od akademske važnosti, već je izravno povezano $s$ kvalitetom života, zdravlja i zdravstvene zaštite, što je osnovni preduvjet za ostanak i preduvjet za opstanak stanovništva na određenom području. Kako bi se osigurao napredak i razvoj društva u cjelini važno je sustavno urediti i ovo područje ljudske djelatnosti na svim razinama (5-7).

Cilj ovog rada je prikazati pravne norme visokoškolskih ustanova u području biomedicine i zdravstva u Bosni i Hercegovini.

\section{Visokoškolsko obrazovanje na razini Bosne i Hercegovine}

Od 2003. godine Ministarstvo civilnih poslova $\mathrm{BiH}$ je u skladu sa svojim nadležnostima pokrenulo inicijative usvajanje više okvirnih zakona iz područja obrazovanja, među kojima je i Okvirni zakon o visokom obrazovanju u $\mathrm{BiH}$. Okvirni zakon o visokom obrazovanja u BiH usvojen je u lipnju 2007. godine, a stupio je na snagu 15. kolovoza 2007. godine, („Službeni glasnik BiH“, br. 59/07). U 2009. godini usvojen je i Zakon o izmjeni i dopuni Okvirnog zakona o visokom obrazovanju u $\mathrm{BiH}$ („Službeni glasnik Bosne i Hercegovine“, broj: 59/09). Okvirni zakon dosljedno je prihvatio glavne odrednice Bolonjskih reformi, tako da su u njega ugrađene osnovne preporuke iz niza do tada usvojenih dokumenata s ministarskih skupova u Europi do 2007. godine. Okvirni zakon nalaže: model integriranog sveučilišta; model studiranja u tri ciklusa; uvođenje europskog sustava prijenosa bodova (ECTS bodovi); jasno određena akademska zvanja i minimalne uvjete za njihovo stjecanje, osnivanje dvije državne agencije u području visokog obrazovanja: Agencije za razvoj visokog obrazovanja i osiguranje kvaliteta (HEA) i Centra za informiranje i priznavanje dokumenata iz područja visokog obrazovanja (CIP). Okvirnim zakonom postavljeni su i rokovi za usklađivanje zakonskih akata na ostalim razinama vlasti (šest mjeseci nakon stupanja na snagu Okvirnog zakona, član 63. stavak 1.), te usklađivanje statuta i drugih općih akata sveučilišta i visokih škola (članak 60. stavak 1.). Okvirnim zakonom visoko obrazovanje definirano je kao djelatnost od posebnoga interesa za $\mathrm{BiH}$, a ustanovljena su temeljna načela i standardi za stjecanje visokog obrazovanja, sukladno relevantnim odredbama Europske konvencije o zaštiti ljudskih prava i temeljnih sloboda (ETS No. 5, 1950) i njezinih protokola, Preporuci Komiteta ministara Vijeća Europe o priznavanju i ocjeni kvalitete privatnih visokoškolskih ustanova [R(97)1], Preporuci o pristupu visokom obrazovanju [R(98)3] i Preporuci o istraživačkoj zadaći sveučilišta $[R(2000) 8]$ te drugim relevantnim načelima međunarodno priznatih pravnih instrumenata, čija je država ugovornica i $\mathrm{BiH}$, te sukladno Konvenciji Vijeća Europe/UNESCO-a o priznavanju kvalifikacija u visokom obrazovanju u europskoj regiji (ETS No. 165, 1997). Okvirnim zakonom $\mathrm{BiH}$ je prihvatila europske strateške ciljeve u području visokog obrazovanja, izražene u Deklaraciji europskih ministara visokog obrazovanja iz Bologne (1999), kao i kasniji razvoj ove koncepcije. Donošenjem Okvirnog zakona $\mathrm{BiH}$ je prešla na „bolonjski“ sustav visokog obrazovanja (8-10).

\section{Temelj, ciljevi i značenje visokog obrazovanja u Bosni i Hercegovini}

Visoko obrazovanje u BiH temelji se na: akademskim slobodama, akademskoj samoupravi i autono- 
miji sveučilišta; otvorenosti sveučilišta prema javnosti, građanima i lokalnoj zajednici; nedjeljivosti nastavnog rada i znanstvenog istraživanja, odnosno umjetničkog stvaralaštva; uvažavanju europskih humanističkih i demokratskih vrijednosti, te usklađivanju s europskim sustavom visokog obrazovanja; poštovanju ljudskih prava i građanskih sloboda, zabrani svih oblika diskriminacije, koncepciji cjeloživotnog obrazovanja; interakciji s društvenom zajednicom i obvezi sveučilišta da razvijaju društvenu odgovornost studenata i drugih članova akademske zajednice.

Okvirnim zakonom o visokom obrazovanju u $\mathrm{BiH}$ su kao ciljevi visokog obrazovanja postavljeni: ustanovljavanje, razvoj, zaštita i prijenos znanja i sposobnosti kroz nastavu i znanstvenoistraživački rad, doprinos razvoju sposobnosti pojedinaca i društva, pružanje mogućnost građanima da, sukladno propisima cijeloga života uživaju korist visokog obrazovanja. Termin "visoko obrazovanje" u $\mathrm{BiH}$ u smislu Okvirnog zakona označava obrazovanje nakon završene srednje škole koje vodi do međunarodno priznatog stupnja visokog obrazovanja.

Visoko obrazovanje u $\mathrm{BiH}$ organizirano je u tri ciklusa:

- prvi ciklus visokog obrazovanja koji vodi do akademskog zvanja završenog dodiplomskog studija (the degree of Bachelor) ili ekvivalenta stečenog nakon najmanje tri i najviše četiri godine redovitog studija nakon stjecanja svjedodžbe o završenoj srednjoj školi, a koji se vrednuje s najmanje 180, odnosno 240 ECTS bodova,

- drugi ciklus visokog obrazovanja koji vodi do akademskog zvanja magistra ili ekvivalenta stečenog nakon završenog dodiplomskog studija, traje jednu ili dvije godine, a vrednuje se s najmanje 60, odnosno 120 ECTS bodova, i to tako da u zbroju s prvim ciklusom nosi 300 ECTS bodova, i

- treći ciklus visokog obrazovanja koji vodi do akademskog zvanja doktora znanosti ili ekvivalenta, te traje tri godine i vrednuje se s 180 ECTS bodova.

Iz navedene podjele izuzet je studij medicine koji se vrednuje do 360 ECTS bodova, a u svakom ciklusu visokog obrazovanja jedan semestar studija nosi opterećenje od 30 ECTS (8).

\section{Vrste visokoškolskih ustanova u Bosni i} Hercegovini

Okvirnim zakonom o visokom obrazovanju u $\mathrm{BiH}$ utvrđena je podjela visokoškolskih ustanova na sveučilišta i visoke škole.

Termin "sveučilište" ograničen je na visokoškolske ustanove koje se bave i nastavnim i istraživačkim radom, koje nude akademske stupnjeve sva tri ciklusa, s ciljevima koji uključuju unapređenje znanja, misli i školstva u BiH, obrazovni, kulturni, društveni i gospodarski razvoj $\mathrm{BiH}$, promoviranje demokratskog građanskog društva i postizanje najviših standarda nastave i istraživačkog rada. Termin "sveučilište" odnosi se na visokoškolsku ustanovu koja realizira najmanje pet različitih studijskih programa iz najmanje tri znanstvena područja: prirodnih znanosti, tehničkih znanosti, biomedicine i zdravstva, biotehničkih znanosti, društvenih znanosti i humanističke znanosti.

Termin "visoka škola” u BiH ograničen je na visokoškolsku ustanovu koja je akreditirana za davanje diploma i stupnja prvog ciklusa visokog obrazovanja, s ciljevima koji uključuju pripremu i obuku pojedinaca za stručni, gospodarski i kulturni razvoj BiH i promoviranje demokratskog građanskog društva, te postizanja visokih standarda nastave i učenja. Termin "visoka škola" odnosi se na visokoškolsku ustanovu koja realizira najmanje jedan studijski program iz jednog znanstvenog područja i ispunjava druge zakonom određene uvjete.

\section{Biomedicina i zdravstvo u zakonodavnim okvirima visokoškolskog obrazovanja u BiH}

U Okvirnom zakonu o visokom obrazovanju u $\mathrm{BiH}$ i u Zakonu o visokom obrazovanju Hercegovačko - neretvanske županije termin biomedicine i zdravstva spominje se samo u dva slučaja i to:

- kao jedno od šest znanstvenih područja iz kojih se izvode studijski programi na visokoškolskim ustanovama,

- kao integrirani studij medicinske grupe znanosti koji se izuzima od podjele na prvi i drugi ciklus visokog obrazovanja i vrednuje s 360 ECTS bodova $(7,11)$.

Zakon o visokom obrazovanju Republike Srpske termin biomedicine i zdravstva također spominje u kontekstu integriranih studija i ostavlja mogućnost 
izuzeća od podjele na prvi i drugi ciklus visokog obrazovanja, odnosno da se studiji medicine i stomatologije izvode kao jedinstveni studijski program koji obuhvata prvi i drugi ciklus studija koji se vrednuju s najmanje 360 ECTS bodova umjesto, kako je to uobičajeno, 300 ECTS bodova.

Zakon o visokom obrazovanju RS ipak je otišao jedan korak dalje, pa je prepoznao važnost nastavnih baza u području biomedicine i zdravstva te ih je na zakonskoj razini definirao kao ustanove iz područja zdravlja i zaštite zdravlja koje se koristi za izvođenje nastavnog procesa za potrebe visokoškolske ustanove.

Zakon o visokom obrazovanju RS predvidio je i da za rektora, prorektora ili dekana može biti izabran profesor $u$ odgovarajućem znanstvenonastavnom zvanju iz kliničkih grana medicine i stomatologije koji je u dopunskom radnom odnosu na visokoškolskoj ustanovi i ima zaključen ugovor o radu s punim radnim vremenom sa zdravstvenom ustanovom koja je nastavna baza visokoškolske ustanove, uz obavezu da prije preuzimanja funkcije zasnuje radni odnos s punim radnim vremenom na visokoškolskoj ustanovi. Isti zakon definirao je i da član znanstveno-nastavnog vijeća može biti i nastavnik u znanstveno-nastavnom zvanju i suradnik u suradničkom zvanju iz kliničkih grana medicine i stomatologije, koji je u dopunskom radu na visokoškolskoj ustanovi i ima zaključen ugovor o radu s punim radnim vremenom sa zdravstvenom ustanovom koja je nastavna baza te visokoškolske ustanove (12).

\section{ZAKLJUČAK}

Visokoškolske ustanove u području biomedicine i zdravstva djeluju u relativno slabo uređenom zakonodavnom okviru. To je vidljivo kada uspoređujemo pravne norme u zemljama u susjedstvu, a osobito u usporedbi sa zemljama Europske unije (13). Iz prethodno navedenog okvira u kojem se razvija visoko obrazovanje u $\mathrm{BiH}$ evidentno je kako je potrebno uklanjanje proturječja među postojećim pravnim normama. Nepostojanje jasno reguliranih pravnih normi dovodi do slabog funkcioniranja u području obrazovanja i istraživanja u području biomedicine i zdravstva, a to je usko povezano is kvalitetom života, zdravlja i zdravstvene zaštite, što je osnovni preduvjet za opstanak i opstojnost stanovništva.

\section{LITERATURA}

1. Ustav Federacije Bosne i Hercegovine ("Sl. novine FBiH”, br. 1/1994, 1/1994 - Amandman I, 13/1997 - Amandmani II-XXIV, 13/1997 - Amandmani XXV i XXVI, 16/2002 - Amandmani XXVII-LIV, 22/2002 - Amandmani LVILXIII, 52/2002 - Amandmani LXIV-LXXXVII, 60/2002 - ispr. Amandmana LXXXI, 18/2003 - Amandman LXXXVIII, 63/2003 - Amandmani LXXXIX-XCIV, 9/2004 - Amandmani XCVCII, 20/2004 - Amandmani CIII i CIV, 33/2004 - Amandman CV, 71/2005 - Amandmani CVICVIII, 72/2005 - Amandman CVI i 88/2008 Amandman CIX)

2. www.cip.gov.ba. Preuzeto sa: http://www.cip. gov.ba (05.09.2020.)

3. www.hea.gov.ba. Preuzeto sa: http://www.hea. gov.ba (11.10.2020.)

4. www.mcp.gov.ba Preuzeto sa: http://www.mcp. gov.ba (17.09.2020.)

5. Mimica M, Babić D, Vasilj I. Važnost i značaj znanosti na Fakultetu zdravstvenih studija. Zdravstveni glasnik. 2015;1:9-12.

6. Šimić Lj. Fakultet zdravstvenih studija Sveučilišta u Mostaru (šesnaest godina postojanja). Zdravstveni glasnik. 2016;1:9-16.

7. Šimić Lj, Šimić J. Značaj osnivanja visokoobrazovnih institucija biomedicinskih znanosti na Sveučilištu u Mostaru. Motrišta. 2017; 93/94: 227-235. preuzeto sa: https://www.ceeol.com/ search/article-detail?id=514630 (18.09.2020.)

8. Okvirni zakon o visokom obrazovanja u Bosne i Hercegovine. („Službeni glasnik BiH“, br. 59/07).

9. Zakon o izmjeni i dopuni Okvirnog zakona o visokom obrazovanju u $\mathrm{BiH}$ („Službeni glasnik Bosne i Hercegovine", broj: 59/09)

10. www. eur-lex.europa.eu. Preuzeto sa: https:// eur-lex.europa.eu/legal-content/HR/TXT/?uri=legissum:c11088 (02.09.2020.)

11. Zakon o visokom obrazovanju u Hercegovačko-neretvanskoj županiji („Službene novine HNŽ broj: 04/12)

12. Zakon o visokom obrazovanju Republike Srpske (Sl. glasnik RS br. 67/2020)

13. Grubišić K. Sistematizacija pravnih normi u visokom obrazovanju i znanosti u Republici Hrvatskoj. Zbornik Pravnog fakulteta: Sveučilište u Zagrebu, 2017. 


\title{
HIGHER EDUCATION INSTITUTIONS IN THE FIELD OF BIOMEDICINE AND HEALTHCARE IN BOSNIA AND HERZEGOVINAH REVIEW OF LEGAL STANDARDS
}

\author{
Vedran Ramljak, Jelena Šimić, Magdalena Ramljak \\ Faculty of Health Studies University of Mostar \\ ${ }^{2}$ Faculty of Humanities and Social Sciences University of Mostar
}

\begin{abstract}
The field of education, and therefore the field of higher education in Bosnia and Herzegovina is in full jurisdiction of ten cantons of the Federation of Bosnia and Herzegovina, Entity of Republika Srpska, and the Brčko District. The Framework Law on Higher Education was adopted in June 2007 and entered into force on August 15 2007. The Framework Law on Higher Education in Bosnia and Herzegovina sets the following goals for higher education: establishment, development, protection and transfer of knowledge, teaching skills and scientific research work, contribution to the development of individual and social capabilities, provide possibilities for lifelong learning to citizens in accordance to regulations. The Framework Law on Higher Education in Bosnia and Herzegovina defines division of higher education institutions to universities and higher schools/colleges.

Higher education institutions in the field of biomedicine and health operate in relatively poorly regulated legal framework. The lack of clearly regulated legal standards leads to the lack of proper functioning of education and scientific research activities in the field of healthcare and biomedicine.
\end{abstract}

Key words: higher education, biomedicine and healthcare, legal standards

Correspondence:

Vedran Ramljak, Mag. iur.

E-mail: vedran.ramljak@fzs.sum.ba 